\title{
Mobilization of energetic substrates in the endangered catfish Steindachneridion parahybae (Siluriformes: Pimelodidae): changes in annual reproductive cycle in captivity
}

\author{
Carlos E. Tolussi ${ }^{1}$, Aline D. Gomes ${ }^{1}$, Cristiéle da S. Ribeiro ${ }^{2}$, Danilo Caneppele ${ }^{3}$, \\ Renata G. Moreira ${ }^{1}$ and Renato M. Honji ${ }^{1,4}$
}

\begin{abstract}
This study aimed at analyzing the energetic substrate (ES) in the main storage tissues of Steindachneridion parahybae, throughout the reproductive cycle in captivity. Differently from wild, in captivity, feeding is not interrupted during the reproductive period, the females do not spawn spontaneously, and they are sedentary. Adult females were sampled monthly and based on their histology and gonadosomatic index (GSI), ovaries were classified into: previtellogenic (PRV), vitellogenic (VTG), and regression (REG) stages. Ovaries at the VTG stage showed higher protein and lipids levels than at the PRV stage with a positive correlation between these substrates and the GSI. Muscle was the main source of proteins transferred to the ovaries, according to the negative correlation between these organs. Lipids remained unchanged in the liver, which is an important supplier in vitellogenesis, a pattern that probably occurs due to the continuous feeding. Muscular glycogen levels were higher at the VTG and REG than at the PRV stages. Plasma triglycerides were also higher during REG, while glucose levels were more elevated during the VTG stage. These results suggest that with constant food supply, the pattern of deposition of ES in S. parahybae is different from that described for other wild potamodromous species.
\end{abstract}

Keywords: Glycogen, Lipids, Metabolic substrate, Protein, Reproductive cycle.

O objetivo deste estudo foi analisar a composição do substrato energético (SE) nos principais tecidos de armazenamento de Steindachneridion parahybae, durante todo o ciclo reprodutivo em cativeiro. Diferentemente do ambiente natural, em cativeiro, a alimentação desses animais não é interrompida durante o período reprodutivo, as fêmeas não desovam espontaneamente, e são sedentárias. Fêmeas adultas foram amostradas mensalmente e baseada na histologia e no índice gonadossomático (IGS), os ovários foram classificados: estádios pré-vitelogênico (PRV), vitelogênico (VTG) e regressão (REG). Os ovários no estádio VTG apresentaram uma maior concentração de lipídeos e proteínas em relação ao estágio PRV. Esses substratos correlacionaram-se positivamente com o IGS. O músculo foi a principal fonte de proteína transferida aos ovários, como foi confirmado pela análise de correlação negativa entre esses órgãos. Os lipídeos mantiveram-se inalterados no fígado, considerado um importante órgão fornecedor de lipídeos para a vitelogênese, padrão que possivelmente ocorreu devido à contínua alimentação. A concentração do glicogênio muscular foi mais elevada durante os estágios VTG e REG em relação ao PRV. A concentração de triglicerídeos plasmática apresentou maiores valores no estádio REG enquanto a concentração de glicose no plasma foi maior durante os estádios VTG. Esses resultados sugerem que com alimentação constante, as fêmeas de S. parahybae apresentam um distinto padrão de mobilização dos substratos energéticos em relação ao que já foi descrito para outras espécies potamódromas de ambiente natural.

Palavras-chaves: Ciclo reprodutivo, Glicogênio, Lipídeos, Proteínas, Substrato metabólico.

\footnotetext{
${ }^{1}$ Departamento de Fisiologia, Instituto de Biociências, Universidade de São Paulo. Rua do Matão, Trav. 14, n³21, 05508-090 São Paulo, SP, Brasil. (CET) ctolussi@usp.br, (ADG) eniladal@usp.br, (RGM) renatagm@ib.usp.br, (RMH) honjijp@usp.br, (Dhttps://orcid.org/0000-0001-7198-7728 (corresponding author)

${ }^{2}$ Departamento de Biologia e Zootecnia, Universidade Estadual Paulista (UNESP), Faculdade de Engenharia, Câmpus de Ilha Solteira. Rua Monção, 226, 15385-000 Ilha Solteira, SP, Brasil. cristiele@bio.feis.unesp.br

${ }^{3}$ Unidade de Hidrobiologia e Aquicultura, Companhia Energética de São Paulo (CESP). Rodovia dos Tamoios, km 38, $12260-000$ Paraibuna, SP, Brasil. danilo.caneppele@cesp.com.br

${ }^{4}$ Centro de Aquicultura, Universidade Estadual Paulista "Júlio de Mesquita Filho" (CAUNESP). Via de Acesso Prof. Paulo Donato Castellane, s/n, 14884-900 Jaboticabal, SP, Brasil.
} 


\section{Introduction}

Several studies have used energetic substrates in teleosts as a model to evaluate storage dynamics and mobilization in fish life cycle under different conditions. These studies evaluated, for instance: (1) the reproductive cycle or reproductive performance of fish in captivity (Izquierdo et al., 2001); (2) larval, juvenile, and adult nutrition (Sargent et al., 1995, 1999; Izquierdo et al., 2001; Andrade et al., 2010; Araújo et al., 2012); (3) smoltification (Björnsson et al., 2011); (4) trophic interrelationship (Lowe-McConnell, 1999; Bittar et al., 2012); and (5) effects of pollutants on energetic substrates (Lima et al., 2011; Vieira et al., 2013). Besides, in several fish species that are candidates for aquaculture, deposition of adequate energetic substrates in the tissues, as liver and ovaries, are essential for a good reproductive performance, successful egg mass, and fingerling production (Fernández-Palacios et al., 2011).

Studies on the improvement of broodstock nutrition show that protein and lipid (including fatty acid) mobilization significantly improves not only egg and sperm quality but also larvae production (Fernández-Palacios et al., 2011; Araújo et al., 2012). Mobilization patterns include the preferential accumulation of energetic substrates among different teleost species. These mobilization patterns change according to reproductive conditions and strategies of oocyte development (Soengas et al., 1993; Sheridan, 1994; Cerdá et al., 1995; Schreck et al., 2001; Jerez et al., 2006). Throughout the reproductive cycle, there are seasonal changes in the biochemical composition (water, lipids, glycogen, and proteins) of fish tissues, especially in females, in which the hepatic metabolism is stimulated during vitellogenesis (Lubzens et al., 2010).

In fish, changes in tissue biochemical composition have been related to gonadal weight, which could reach 15 to $45 \%$ of body mass in females and 3.7\% in males (Tyler, Sumpter, 1996). This increase in gonadal mass observed in females is primarily due to vitellogenesis, triggered by the vitellogenin synthesis (Jalabert, 2005; Reading, Sullivan, 2011). Vitellogenin is produced in the liver under the regulation of the gonadal steroid 17 $\beta$-estradiol, and incorporated to the oocytes as yolk proteins, providing the main nutrients required for larval development (Reading, Sullivan, 2011). During this process, there is usually a decrease in lipids from the liver and adipose tissue (Moreira et al., 2002; Blanchard et al., 2005; Jalabert, 2005) and proteins, which are mobilized to the ovaries development. According to theoretical studies, the energetic need during vitellogenesis corresponds to twothirds of the energy spent during spawning (Pecquerie et al., 2009), which shows the high metabolic cost of this process. Additionally, in migratory fish, such as salmonids, migration is accompanied by a hypophagic state, i.e, the animals do not eat (Hochachka, Somero, 2002), and energetic substrates (initially lipids, then proteins, and at last carbohydrates) are mobilized to sustain migration (Mommsen et al., 1980). However, when there is no longer a migratory behavior, as in captivity, migratory fish especially potamodromous species, do not stop eating before the reproductive season, and commonly the females do not spawn (Honji et al., 2009).

Steindachneridion parahybae (Steindachner, 1877), locally known as surubim-do-Paraiba, is an example of potamodromous teleost. It is a Neotropical catfish (gonochoristic, medium-sized), endemic to the Paraíba do Sul River Basin, critically endangered in the Brazilian red list, and considered regionally extinct in the state of São Paulo (Garavello, 2005; Caneppele et al., 2009; Honji et al., 2009, 2012, 2013, 2015, 2016, 2017). Besides this critical situation, the maintenance of $S$. parahybae female broodstock in fish farms is not entirely successful, as females do not reproduce when reared in captivity, i.e, females fail to ovulate or spawn naturally (Honji et al., 2015), despite their continuous feeding. Since 2003, the energy company Companhia Energética de São Paulo (CESP) has funded studies on the biology of $S$. parahybae. These studies include the maintenance and management of broodstocks in captivity, egg and sperm quality, and successful larval rearing (Honji et al., 2009, 2012, 2013, 2015, 2016, 2017; Sanches et al., 2013, 2014, 2015). They aim at ensuring successful and controlled breeding programs, involving conservation actions and a fish restocking program.

In the last few years, our research group and collaborators have advanced the knowledge on fundamental aspects of the reproductive biology of $S$. parahybae in captivity (Caneppele et al., 2009, 2015; Honji et al., 2012, 2013, 2015, 2016, 2017; Sanches et al., 2013, 2014, 2015; Lopes et al., 2015). Knowledge of mobilization and deposition of energetic substrates on different tissues linked to their function in the reproductive cycle is required to understand the energetic requirement of $S$. parahybae, support further studies on broodstock nutrition, and contribute to the conservation of the species. Hence, the objective of the present study was to describe the energetic substrate deposition in the main reserve tissues in adult female $S$. parahybae in captivity throughout the reproductive cycle. Our hypothesis is that the absence of a hypophagic state in captivity changes the pattern of energetic substrate mobilization observed in wild migratory species.

\section{Material and Methods}

Experimental design and collection of animals. The experiment was carried out at the Unidade de Hidrobiologia e Aquicultura, Companhia Energética de São Paulo (CESP) located in Paraibuna, state of São Paulo, southeastern Brazil. Adult specimens of $S$. parahybae (F1) used in our study came from artificially induced reproduction made with wild broodstock (F0) at the same unit (Caneppele et al., 2009). In December 2007, one hundred S. parahybae females born and raised in CESP were selected on the basis of the typical morphological characteristics of sexual ripeness, according to the principles previously established for this species (Caneppele et al., 2009). Briefly, the females were selected 
by the external characteristics, as the hyperemic genital pore and swollen abdomen. Males were chosen according to the presence of running sperm when the abdominal region was gently massaged. Then, they were randomly divided into two ponds $\left(200 \mathrm{~m}^{2}\right)$ (duplicate) with concrete walls and a sandy bottom. During the experiment, the broodstocks were fed with commercial extruded feed for carnivorous fish containing $40 \%$ of crude protein at a rate of $2 \%$ biomass/day, offered twice a day (according to CESP fish farm routine), at 08:00 and 16:00h, following previously studies (Honji, 2011; Honji et al., 2012, 2013, 2016). During the experiment, the water temperature was $21.10 \pm 0.14{ }^{\circ} \mathrm{C}$ and the dissolved oxygen was $7.58 \pm 0.36 \mathrm{mg} / \mathrm{L}$, without significant variation between tanks. The concentration of these two parameters was monitored with an oximeter, Horiba-ModU10.

Monthly, from January 2008 to March 2009 (except June, July and August, winter months), four animals were randomly picked from the ponds (four animals/pond, eight in total, in each sampling event), and transported to the CESP laboratory. We chose not to handle the animals in the fish ponds during these months to avoid the stress and emergence of diseases, such as the one caused by the ciliate Ichthyophthirius multifiliis, avoiding the known risks of mortality during these months (Hurst, 2007). Fish were anesthetized with $0.1 \%$ benzocaine (ethyl-paminobenzoate) following the literature (Gilderhus, 1990; Morato-Fernandes et al., 2013); and each animal had the total length $(\mathrm{cm})$ and total body weight $(\mathrm{g})$ recorded. Then, fish were killed by decapitation at the level of the operculum and dissected. After that, ovaries and liver were quickly removed and weighed. Gonadosomatic (GSI) and hepatosomatic (HSI) index was estimated for each individual. GSI is expressed as the percentage of body weight related to ovaries [GSI = (gonad weight/ total weight) $\mathrm{x} 100$ ], whereas HSI is the percentage of body weight represented by the liver [HSI = (liver weight/ total weight) X 100] (Vazzoler, 1981, 1996). Plasma, ovaries, liver, epaxial muscle samples were collected and stored at $-80^{\circ} \mathrm{C}$ until the analysis of energetic substrates. The present study was conducted in compliance with the Animal Ethics Committee of the Institute of sciences, Biosciences, University of São Paulo (Protocol 072/2008). Additionally, some examined specimens were deposited in the collection of the Laboratory of Metabolism and Reproduction of Aquatic Organisms (Laboratório de Metabolismo e Reprodução de Organismos Aquáticos LAMEROA) of the Institute of Biosciences of University of São Paulo (IBUSP) (number 01, 02), and animals from the same production batch were collected and stored in the fish collection of the Zoological Museum of São Paulo University - MZUSP, with catalog number 100672, 108433, 122965, and 122966.

To determinate gonads maturity stage, GSI and histological analyzes of the ovaries were used. From the GSI analysis three stages of gonadal development could be observed as described by Honji (2011): previtellogenic
(PRV), vitellogenic (VTG), and regression (REG). The pattern of adipose tissue deposition was observed macroscopically; however it was not possible to perform a quantitative analysis.

Energetic substrates. Total proteins from the tissues (epaxial muscle, ovaries, and liver) were extracted with perchloric acid $6 \%$ (precipitation) and potassium hydroxide $2.5 \%$ (solubilization), following Milligan, Girard (1993). Tissue and plasma proteins levels were determined by the colorimetric method of Lowry et al. (1951), using bovine serum albumin as standard (Bovine serum albumin, Sigma Diagnostics, St. Louis, MO, USA), measured at $660 \mathrm{~nm}$, and expressed as $\mathrm{mg} / \mathrm{g}$.

Total lipids from the epaxial muscle, ovaries and liver were extracted with a mixture of chloroform, methanol, and water (2:1:0.5), following Folch et al. (1957) modified by Parrish (1999) for aquatic organisms. Next, the total lipid content in tissues and plasma was quantified by the enzymecolorimetric method, following Frings et al. (1972), using cod liver oil (Cod liver oil fatty acid methyl esters, Sigma Diagnostics, St. Louis, MO, USA) to yield the standard curve, measured at $540 \mathrm{~nm}$, and expressed as $\mathrm{mg} / \mathrm{g}$.

Glycogen level from the epaxial muscle and liver was extracted with potassium hydroxide $(1 \mathrm{~mL} ; 6 \mathrm{~N})$, following Bidinotto et al. (1997). Glycogen levels were quantified following DuBois et al. (1956), with the hydrolytic method using D-glucose (Sigma Diagnostics INS) as the standard curve at $480 \mathrm{~nm}$ and expressed in $\mu \mathrm{mols}$ glucose $/ \mathrm{g}$.

Plasma glucose level was measured using a Glucose Monoreagent kit $\left(\right.$ Bioclin $\left.^{\circledR}\right)$ with colorimetric enzymatic reaction, following the manufacturer's guidelines. The reading was performed on a microplate reader (Spectra Max 250, Molecular Devices) at a wavelength of $505 \mathrm{~nm}$. The plasma cholesterol and triglycerides level were analyzed with a Cholesterol and Triglycerides Monoreagent kit $\left(\right.$ Bioclin $\left.^{\circledR}\right)$ also with colorimetric enzymatic reaction, following the manufacturer's guidelines. The reading was performed on a microplate reader (Spectra Max 250, Molecular Devices) at a wavelength of $500 \mathrm{~nm}$ for both.

Statistical analysis. Energetic substrates (lipids, protein, glycogen, glucose, triglycerides and cholesterol) from each tissue analyzed (liver, muscle and ovaries) and plasma were compared according to the maturation stage (PRV, VTG, and REG), using one-way analysis of variance (ANOVA), followed by Bonferroni Test. The statistical difference was significant when $P<0.05$. The analyses were made in the statistical software SigmaStat for Windows (Advisory Statistics for Scientists, Systat Software Inc, Copyright, version 3.10). The energetic substrates concentration from tissues, the values of GSI and HSI were transformed to $\log 10$ to normalize the data and the Pearson Correlation Test was applied (BioEstat Statistical Program, version 8.0). Data were expressed as mean \pm standard error ( $\mathrm{M} \pm$ SEM). 


\section{Results}

Tab. 1 presents the biometrical parameters (total length and total body mass), HSI, and GSI index; tissues and plasma energetic substrate levels during annual reproductive cycle (PRV, VTG, and REG stages). Females consumed all the feed given ( $2 \%$ of the biomass, daily) during the reproductive cycle, without any hypophagic period. In addition, all females maintained a high deposition of adipose tissue along the digestive tract, throughout the year. The GSI increased from the PRV to the VTG stage $(P<$ $0.01)$ and decreased at the REG stage $(P<0.01)$. The HSI did not presented significant statistical difference during the reproductive cycle $(P=0.349)$.

Tab 1. Steindachneridion parahybae: Biometrical parameters (total length and total body mass); hepatosomatic (HSI) and gonadosomatic (GSI) index; tissues and plasma energetic substrate levels during annual reproductive cycle (PRV: previtellogenic; VTG: vitellogenic; and REG: regression stages). Data are presented as the mean \pm standard error of the mean. $n$ total number of individuals analyzed; TL - total length; TW - total body mass; GSI - gonadosomatic index; HSI Hepatosomatic index. ab Statistical difference among reproductive stages $(P<0.05)$.

\begin{tabular}{|c|c|c|c|c|}
\hline & Parameters/Tissues & $\operatorname{PRV}(n=20)$ & VTG $(n=12)$ & $\operatorname{REG}(n=8)$ \\
\hline \multirow{4}{*}{ Biometric parameters } & $\mathrm{TL}(\mathrm{cm})$ & $41.30 \pm 0.48$ & $40.04 \pm 0.75$ & $38.09 \pm 0.72$ \\
\hline & TW (g) & $698.58 \pm 30.02$ & $692.46 \pm 40.17$ & $534.45 \pm 28.37$ \\
\hline & GSI (\%) & $0.52 \pm 0.07^{\mathrm{a}}$ & $1.68 \pm 0.36^{\mathrm{b}}$ & $0.90 \pm 0.10^{\mathrm{a}}$ \\
\hline & HSI (\%) & $0.70 \pm 0.04$ & $0.78 \pm 0.05$ & $0.76 \pm 0.05$ \\
\hline \multirow{3}{*}{ Proteins } & Muscle (mg/g) & $327.36 \pm 31.13^{\mathrm{a}}$ & $184.89 \pm 25.94^{b}$ & $269.82 \pm 15.90^{\mathrm{ab}}$ \\
\hline & Ovaries (mg/g) & $209.66 \pm 8.74^{\mathrm{a}}$ & $294.89 \pm 18.45^{b}$ & $281.33 \pm 11.72^{b}$ \\
\hline & Liver $(\mathrm{mg} / \mathrm{g})$ & $118.74 \pm 5.09$ & $112.65 \pm 10.69$ & $135.69 \pm 11.61$ \\
\hline \multirow{3}{*}{ Lipids } & Muscle (mg/g) & $5.33 \pm 0.97$ & $4.41 \pm 0.79$ & $5.58 \pm 0.85$ \\
\hline & Ovaries (mg/g) & $17.58 \pm 2.44^{\mathrm{a}}$ & $33.52 \pm 2.73^{b}$ & $24.18 \pm 3.01^{\mathrm{ab}}$ \\
\hline & Liver (mg/g) & $14.75 \pm 2.23$ & $15.66 \pm 2.55$ & $15.00 \pm 1.07$ \\
\hline \multirow{2}{*}{ Glycogen } & Muscle (m mols glucose/g) & $3.23 \pm 0.48^{\mathrm{a}}$ & $6.63 \pm 0.73^{b}$ & $10.86 \pm 1.52^{b}$ \\
\hline & Liver (m mols glucose/g) & $409.60 \pm 58.08$ & $448.88 \pm 68.94$ & $385.04 \pm 41.91$ \\
\hline \multirow{5}{*}{ Plasma } & Lipids (mg/mL) & $0.06 \pm 0.00$ & $0.06 \pm 0.00$ & $0.06 \pm 0.00$ \\
\hline & Proteins $(\mathrm{mg} / \mathrm{mL})$ & $49.67 \pm 1.14$ & $48.55 \pm 1.37$ & $47.36 \pm 1.60$ \\
\hline & Triglycerides (mg/dL) & $178.69 \pm 8.53^{\mathrm{a}}$ & $169.99 \pm 14.89^{\mathrm{a}}$ & $249.43 \pm 43.96^{\mathrm{b}}$ \\
\hline & Glucose (mg/dL) & $49.39 \pm 2.23^{\mathrm{a}}$ & $69.75 \pm 6.21^{b}$ & $66.50 \pm 2.46^{\mathrm{b}}$ \\
\hline & Cholesterol (mg/dL) & $195.45 \pm 11.00$ & $190.15 \pm 7.91$ & $215.88 \pm 15.78$ \\
\hline
\end{tabular}

Energetic substrates. Females at VTG and REG stages showed higher total protein concentration in ovaries than at PRV stage $(P<0.001)$. In the epaxial muscle, higher protein concentration was observed at PRV stage, decreased at VTG stage and remained unchanged during the REG stage $(P$ $=0.012$ ). Hepatic protein levels did not change during the annual reproductive cycle, as well as its total protein plasma level. Similarly to protein levels, females at VTG stage showed higher total lipids levels in ovaries than at PRV stage $(P<0.001)$. The lipid content remained unchanged during REG stage. Hepatic and muscular lipid levels did not change during the annual reproductive cycle, as well as its plasma level. Glycogen concentration was higher in $S$. parahybae muscle at VTG and REG stages than at PRV stage $(P<0.001)$. However, this substrate did not change in the hepatic tissue during the reproductive cycle. The results of plasma substrate levels showed that glucose was lower $(P<0.001)$ in PRV than VTG and REG stages. However, triglycerides levels in REG was higher $(P=0.027)$ than in other stages. Cholesterol did not show change throughout the reproductive cycle.

In the correlation analysis, ovarian proteins and lipids showed a positive correlation with GSI, whereas muscle protein showed a negative correlation with ovarian protein
(Tab. 2). The HSI showed a positive correlation with hepatic glycogen, a negative correlation with hepatic protein and no correlation with GSI. Ovarian lipids showed a positive correlation with hepatic lipids (Tab. 2).

Tab. 2. Steindachneridion parahybae: Pearson correlation among metabolic parameters (total lipids, protein and glycogen) and somatic indexes (gonadosomatic (GSI) and hepatosomatic (HSI) indexes) and tissues (epaxial muscle, ovarian and liver) sampled throughout the reproductive period. Values that indicate correlations are presented $(P<0.05)$.

\begin{tabular}{|c|c|c|c|}
\hline Lipids & Ovaries & Liver & GSI \\
\hline Muscle & - & - & \\
\hline Liver & 0.67 & - & \\
\hline HSI & - & - & \\
\hline GSI & 0.54 & - & \\
\hline \multicolumn{4}{|c|}{ Protein } \\
\hline Muscle & -0.35 & - & \\
\hline HSI & - & -0.55 & \\
\hline GSI & 0.81 & - & \\
\hline \multicolumn{4}{|c|}{ Glycogen } \\
\hline HSI & - & 0.34 & - \\
\hline
\end{tabular}




\section{Discussion}

In this study, we described the deposition of energetic substrates in the main reserve tissues throughout the reproductive cycle. We highlight that the absence of both, migration and the hypophagic phase, affected the pattern of substrate mobilization, especially regarding lipids.

Morphological indices, such as GSI and HSI, have been used to express the dynamics of energetic substrates in gonads and liver, respectively (Collins, Anderson, 1995). These indices, together with the gonadal histology (Vazzoler, 1996) and biochemical composition analyses can be quantitative indicators of the reproductive period and energetic investment in reproduction (Marcano et al., 2007). GSI was higher in $S$. parahybae females with fully developed ovaries (VTG stage), whereas the lowest GSI value occurred at the PRV stage, which evidenced that ovaries performed vitellogenesis, even in captivity. The ovarian histological analyses in these animals confirmed this fact (Honji, 2011). In contrast, HSI remained unchanged throughout the reproductive cycle and did not correlate with GSI. In some wild fish species carnivorous an inverse correlation between GSI and HSI have been observed such as Ctenolabrus rupestris (Sayer et al., 1995), Perca fluviatilis (Blanchard et al., 2005) and Curimatella lepidura (Alvarenga et al., 2006). It suggests an intense mobilization of energetic substrates from the liver to ovaries during vitellogenesis, when the feeding activity is reduced or interrupted (Bennemann et al., 1996). In captivity, S. parahybae was fed daily during the reproductive cycle. Therefore, this nutritional status can abolish the need for depletion of liver substrates, maintaining unchanged HSI values throughout the year, even with an intense increase in GSI.

Lipids and protein are the most important substrates involved in fish reproduction due to their role as structural and energetic source to the embryo development (Yaron, Sivan, 2006). The lipid content in ovaries, its positive correlation with the GSI, and histological findings (Honji, 2011) suggest the incorporation of this substrate in oocytes, through of vitellogenin or other lipoproteins of the yolk (Lubzens et al., 2010). Perca fluviatilis, a carnivorous fish (Blanchard et al., 2005) and Percophis brasiliensis, an omnivorous species (Rodrigues et al., 2013), importance of hepatic lipids in the process of vitellogenesis (Lubzens et al., 2010), this energetic substrate did not change in $S$. parahybae females during the reproductive cycle, as also observed in the HSI and muscle lipids. These data suggest that lipids from liver and muscle could be transferred to oocytes, but due to the constant feeding, the content of this energetic substrate is rapidly recovered as described in compensatory growth (Ali et al., 2003). Conversely, in Diplodus sargus (Pérez et al., 2007) and Merluccius merluccius (Domínguez-Petit et al., 2010) lipids increased in liver and muscle during the reproductive period, which was not characterized by reduced or interrupted feeding. So, in stable environments, dietary intake can be directly responsible for lipid accumulation in ovaries (Pérez et al., 2007).
Similarly to lipids, protein content in ovaries was higher in females at the VTG stage, as a result of the yolk incorporation in oocytes (Jalabert, 2005). Besides, protein content was higher than lipids, as the vitellogenin incorporated in the oocytes shows a composition of $19 \%$ of lipids and $79 \%$ of proteins (Yaron, Sivan, 2006). Additionally, the positive correlation between the GSI and ovarian proteins and lipids evidenced the contribution of these substrates to development oocytes. In females at the VTG stage, muscle protein levels decreased and it was observed a negative correlation between muscle and ovarian protein suggesting a possible mobilization this substrate between these organs. Besides that, it is likely that proteins derived directly from the diet also contributed to the vitellogenin synthesis, even considering that the animals did not stop eating.

Hepatic substrates and the HSI did not change during the annual cycle. The variation of liver protein is not expected, because the liver has a major role in the synthesis, metabolism, and transport of this substrate but no a storage function for protein (Bruslé, Anadon, 1996). In Salminus brasiliensis, another tropical potamodromous species, the levels of hepatic protein did not change during the reproductive cycle in the wild (Moreira et al., 2002). Lipids are considered the primary source for reproduction, especially in migratory fish. These highly energetic molecules, mainly in the form of triacylglycerol, are mobilized from the adipose tissue, muscle, and liver to be used in processes of high energetic demand, such as reproduction (Tocher, 2003). Lipids were incorporated in $S$. parahybae oocytes; however, the hepatic and muscular deposit did not change during the reproductive cycle, which suggests that the adipose tissue also was the major source of the lipids used in vitellogenesis even its feeding condition of the animals, a situation that maintained the adipose tissue deposits during the reproductive cycle. In the wild, reophilic fish increased the energy demand and showed a sharp reduction in food frequency during reproductive stages (Jonsson, Jonsson, 1993). Such situation did not occur in the present study; here, females maintained the same feeding activity ( $2 \%$ of body mass daily) throughout the year, and, consequently their adipose tissue stocks, reducing the role of liver and muscle as lipids sources for vitellogenesis.

The glycogen provides the energy necessary for a short-time rather than a long-time demand. The amount of glycogen stored in the liver depends on physical, chemical, and biological factors faced by the fish (Coban, Sen, 2011). These same authors also mention that the rapid movement, stress, and environmental hypoxia decrease carbohydrate reserves (first glycogen in the liver and muscle) but glycogen plays a minor role in oocyte development. In carnivorous species such as Gadus morhua (Lambert, Dutil, 1997), Onchorhynchus mykiss (Barciela et al., 1993) and Capoeta umbla (Coban, Sen, 2011), liver glycogen and condition factor were changed during the reproductive season. These 
results did not corroborate with the present study, where $S$. parahybae did not change hepatic glycogen throughout the reproductive cycle, probably due to the daily intake of food in captivity. However, this carbohydrate is accumulated in muscle during the REG stage.

Higher plasma levels of glucose were found in VTG and REG stages. In Oncorhynchus mykiss, also from captivity, the peak of plasma glucose was observed during maturation stage (Kocaman et al., 2005), demonstrating that glucose seems to be important to vitellogenesis process; however there is little information about this substrate during the reproduction. Plasma triglycerides levels were also higher values in REG stage, different from O. mykiss, where the higher triglyceride values were found during pre-maturation and maturation stages (Kocaman et al., 2005). These distinct results emphasize that the absence of spawning changed the substrates mobilization/deposition process, reflecting in a possible reabsorption process of triglycerides to the others tissues during REG stage.

In conclusion, in Steindachneridion parahybae the muscle is the main source of ovarian protein while hepatic energetic substrates remain unchanged. In the plasm the elevated level of glucose in VTG and REG seems to be important to vitellogenesis process and the higher triglycerides concentration in REG stage can be explained for absence of spawning changed the substrates mobilization/deposition process, reflecting in a possible reabsorption process of triglycerides to the others tissues. The process of mobilization of energetic substrates during the reproductive cycle in S. parahybae females, in captivity and with constant food supply, occurs at different way than described for other potamodromous fish, in the wild, corroborating our hypothesis. Muscle is the main source of ovarian protein while hepatic energetic substrates remain unchanged in S. parahybae.

\section{Acknowledgments}

The authors thank the CESP (Companhia Energética de São Paulo) for granting us access to the fish farm facilities and the staff of LAMEROA (Laboratório de Metabolismo e Reprodução de Organismos Aquáticos) for their help with data collection. This present study was supported by the FAPESP (Fundação de Amparo à Pesquisa do Estado de São Paulo), which gave us a research grant (FAPESP: 2008/57687-0) and a PhD scholarship (FAPESP: 2007/55494-7).

\section{References}

Ali M, Nicieza A, Wootton RJ. Compensatory growth in fishes: a response to growth depression. Fish Fish. 2003; 4(2):147-90.

Alvarenga ER, Bazzoli N, Santos GB, Rizzo E. Reproductive biology and feeding of Curimatella lepidura (Eigenmann \& Eigenmann) (Pisces, Curimatidae) in Juramento reservoir, Minas Gerais, Brazil. Rev Bras Zool. 2006; 23(2):314-22.
Andrade VXL, Honji RM, Romagosa E. Processo de maturação das gônadas de pintado (Pseudoplatystoma corruscans) alimentado com dois níveis proteicos e suplementados com óleo de milho. Arq Bras Med Vet Zootec. 2010; 62(2):332-42.

Araújo BC, Honji RM, Mello PH, Moreira RG. The influence of captive breeding on the fatty acid profiles of Salminus hilarii (Characiformes: Characidae) eggs and larvae. Aquacult Int. 2012; 20(6):1161-81.

Barciela P, Soengas JL, Rey P, Aldegunde M, Rozas G. Carbohydrate metabolism in several tissues of rainbow trout, Oncorhynchus mykiss, is modified during ovarian recrudescence. Comp Biochem Physiol B. 1993; 106(4):943-48.

Bennemann ST, Orsi ML, Shibatta OA. Atividade alimentar de espécies de peixes do rio Tibagi, relacionada com o desenvolvimento de gorduras e gônadas. Rev Bras Zool. 1996; 13(2):501-12.

Bidinotto PM, Moraes G, Souza RHS. Hepatic glycogen and glucose in eight tropical freshwater teleost fish: a procedure for field determinations of micro samples. B Téc CEPTA. 1997; 10(1):53-60.

Bittar VT, Awabdi DR, Tonini WCT, Junior MVV, Beneditto APMD. Feeding preference of adult females of ribbonfish Trichiurus lepturus through prey proximate-composition and caloric values. Neotrop Ichthyol. 2012; 10(1):197-203.

Björnsson BT, Stefansson SO, McCormick SD. Environmental endocrinology of salmon smoltification. Gen Comp Endocrinol. 2011; 170(2):290-98.

Blanchard G, Druart X, Kestemont P. Lipid content and fatty acid composition of target tissues in wild Perca fluviatilis females in relation to hepatic status and gonad maturation. J Fish Biol. 2005; 66(1):73-85.

Bruslé J, Anadon GG. The structure and function of fish liver. In: Datta Munshi JS, Dutta HM, editors. Fish morphology: Horizon of new research. Lebanon: Science Publishers Inc; 1996. p.77-93.

Caneppele D, Honji RM, Hilsdorf AWS, Moreira RG. Induced spawning of the endangered Neotropical species Steindachneridion parahybae (Siluriformes: Pimelodidae). Neotrop Ichthyol. 2009; 7(4):759-62.

Caneppele D, Sanches EA, Romagosa E. Sperm production of Steindachneridion parahybae (Steindachner 1877) and the effect of hormonal induction throughout one reproductive cycle. J Appl Ichthyol. 2015; 31(S1):54-61.

Cerdá J, Zanuy S, Carrillo M, Ramos J, Serrano R. Short- and long-term dietary effects on female sea bass (Dicentrarchus labrax): seasonal changes in plasma profiles of lipids and sex steroids in relation to reproduction. Comp Biochem Physiol C. 1995; 111 (1):83-91.

Coban MZ, Sen D. Examination of liver and muscle glycogen and blood glucose levels of Capoeta umbla (Heckel, 1843) living in Hazar lake and Keban Dam Lake (Elazig, Turkey). Afr J Biotechnol. 2011; 10(50):10271-79.

Collins AL, Anderson TA. The regulation of endogeneous energy stores during starvation and refeeding in the somatic tissues of the golden perch. J Fish Biol. 1995; 47(6):1004-15. 
Domínguez-Petit R, Saborido-Rey F, Medina I. Changes of proximate composition, energy storage and condition of European Hake (Merluccius merluccius, L. 1758) through the spawning season. Fish Res. 2010; 104(1):73-82.

DuBois M, Gilles KA, Hamilton JK, Rebers PA, Smith F. Colorimetric method for determination of sugars and related substances. [Anal Chem. 1956; 28(3):350-56.

Fernández-Palacios $\mathrm{H}$, Norberg $\mathrm{B}$, Izquierdo $\mathrm{M}$, Hamre $\mathrm{K}$. Effects of broodstock diet on eggs and larvae. In: Holt GJ, editor. Larval fish nutrition. Ames: Wiley-Blackwell; 2011. p.151-265.

Folch J, Lees M, Stanley GHS. A simple method for the isolation and purification of total lipides from animal tissues. J Biol Chem. 1957; 226(1):497-509.

Frings CS, Fendley TW, Dunn RT, Queen CA. Improved determination of total serum lipids by the sulfo-phospho-vanillin reaction. Clin Chem. 1972; 18(7):673-74.

Garavello JC. Revision of genus Steindachneridion (Siluriformes: Pimelodidae). Neotrop Ichthyol. 2005; 3(4):607-23.

Gilderhus PA. Benzocaine as a fish anesthetic: efficacy and safety for spawning-phase salmon. Prog Fish-Cult. 1990; 52(3):181-91.

Hochachka PW, Somero GN. Biochemical adaptation: Mechanism and process in physiological evolution. New York: Oxford University Press; 2002.

Honji RM, Caneppele D, Hilsdorf AWS, Moreira RG. Threatened fishes of the world: Steindachneridion parahybae (Steindachner, 1877) (Siluriformes: Pimelodidae). Env Biol Fish. 2009; 85(3):207-08.

Honji RM, Caneppele D, Moreira RG. Caracterização macroscópica das gônadas durante a reprodução induzida em cativeiro do surubim-do-paraíba. Pesq Agropec Bras. 2013; 48(8):1110-14.

Honji RM, Caneppele D, Pandolfi M, Lo Nostro FL, Moreira RG. Gonadotropins and growth hormone family characterization in an endangered Siluriform species, Steindachneridion parahybae (Pimelodidae): relationship with annual reproductive cycle and induced spawning in captivity. Anat Rec. 2015; 298(7):1644-58.

Honji RM, Caneppele D, Pandolfi M, Lo Nostro FL, Moreira RG. A case of intersex occurrence in Steindachneridion parahybae (Steindachner, 1877) (Siluriformes: Pimelodidae) under captivity condition: a cytogenetic and morphological study. Neotrop Ichthyol. 2016; 14(4):e160077.

Honji RM, Tolussi CE, Caneppele D, Polaz CN, Hilsdorf AWS, Moreira RG. Biodiversidade e conservação da ictiofauna ameaçada de extinção da bacia do rio Paraíba do Sul. Rev Biol. 2017; 17(2):18-30.

Honji RM, Tolussi CE, Mello PH, Caneppele D, Moreira RG. Embryonic development and larval stages of Steindachneridion parahybae (Siluriformes: Pimelodidae): implications for the conservation and rearing of this endangered Neotropical species. Neotrop Ichthyol. 2012; 10(2):313-27.

Honji RM. Controle do eixo hipotálamo-hipófise-gônadas do surubim do Paraíba Steindachneridion parahybae (Siluriformes: Pimelodidae) em relação ao ciclo reprodutivo e à reprodução induzida em cativeiro. [Ph.D. Thesis], São Paulo, SP; Universidade de São Paulo. 2011.
Hurst TP. Causes and consequences of winter mortality in fishes. J Fish Biol. 2007; 71(2): 315-45.

Izquierdo MS, Fernández-Palacios H, Tacon AGJ. Effect of broodstock nutrition on reproductive performance of fish. Aquaculture. 2001; 197(1):25-42.

Jalabert B. Particularities of reproduction and oogenesis in teleost fish compared to mammals. Reprod Nutr Dev. 2005; 45(3):261-79.

Jerez S, Rodríguez C, Cejas JR, Bolaños A, Lorenzo A. Lipid dynamics and plasma level changes of 17beta-estradiol and testosterone during the spawning season of gilthead seabream (Sparus aurata) females of different ages. Comp Biochem Physiol B. 2006; 143 (2):180-89.

Jonsson B, Jonsson N. Partial migration: niche shift versus sexual maturation in fishes. Rev Fish Biol Fisher. 1993; 3(4):348-65.

Kocaman EM, Yanik T, Erdogan O, Çiltas AK. Alterations in cholesterol, glucose and triglyceride levels in reproduction of rainbow trout (Oncorhynchus mykiss). J Anim Vet Adv. 2005; 4(9):801-04.

Lambert Y, Dutil J. Can simple condition indices be used to monitor and quantify seasonal changes in the energy reserves of Atlantic cod (Gadus morhua)? Can J Fish Aquat Sci. 1997; 54(S1):104-12.

Lima RL, Braun N, Kochhann D, Lazzari R, Neto JR, Moraes BS, Loro VL, Baldisserotto B. Survival, growth and metabolic parameters of silver catfish, Rhamdia quelen, juveniles exposed to different waterborne nitrite levels. Neotrop Ichthyol. 2011; 9(1):147-52.

Lopes TS, Sanches EA, Okawara RY, Romagosa E. Chilling of Steindachneridion parahybae (Siluridormes: Pimelodidae) embryos. Theriogenology. 2015; 84(4):538-44.

Lowe-McConnell, RH. Ecological studies in tropical fish communities. Cambridge: Cambridge University Press; 1999. (Tropical Biology Series).

Lowry OH, Rosebrough NJ, Farr AL, Randall RJ. Protein measurement with the Folin phenol reagent. \ Biol Chem. 1951; 193(1):265-75.

Lubzens E, Young G, Bobe J, Cerdà J. Oogenesis in teleosts: how eggs are formed. Gen Comp Endocrinol. 2010; 165(3):367-89.

Marcano D, Cardillo E, Rodriguez C, Poleo G, Gago N, Guerrero HY. Seasonal reproductive biology of two species of freshwater catfish from the Venezuelan floodplains. Gen Comp Endocrinol. 2007; 153(3):371-77.

Milligan CL, Girard SS. Lactate metabolism in rainbow trout. J Exp Biol. 1993; 180(1):175-93.

Mommsen TP, French CJ, Hochachka PW. Sites and patterns of protein and amino acid utilization during the spawning migration of salmon. Can J Zool. 1980; 58(10):1785-99.

Morato-Fernandes L, Tavares RA, Rocha CB, Pouey JLOF, Piedras SRN. Benzocaine and clove oil as anesthetics for pejerrey (Odontesthes bonariensis) fingerlings. Arq Bras Med Vet Zootec. 2013; 65(5):1441-46.

Moreira RG, Venturieri RLL, Mimura OM. Lipid and protein alteration in the liver and plasma of the migratory teleost Salminus maxillosus during the reproductive cycle. J Aquacult Trop. 2002; 17(3):209-19. 
Parrish CC. Determination of total lipid, lipid classes and fatty acids in aquatic samples. In: Arts MT, Wainman BC, editors. Lipids in Freshwater Ecosystems. New York: Springer; 1999. p.4-12.

Pecquerie L, Petitgas P, Kooijman SALM. Modeling fish growth and reproduction in the context of the dynamic energy budget theory to predict environmental impact on anchovy spawning duration. J Sea Res. 2009; 62(2-3):93-105.

Pérez MJ, Rodríguez C, Cejas JR, Martín MV, Jerez S, Lorenzo A. Lipid and fatty acid content in wild white seabream (Diplodus sargus) broodstock at different stages of the reproductive cycle. Comp Biochem Physiol B. 2007; 146(2):187-96.

Reading BJ, Sullivan CV. Vitellogenesis in fishes. In: Farrel AP, editor. Encyclopedia of fish physiology: from genome to environment. London: Elsevier; 2011. p.635-638.

Rodrigues KA, Macchi GJ, Massa A, Militelli M. Seasonal analysis of condition, biochemical and bioenergetic indices of females of Brazilian flathead, Percophis brasiliensis. Neotrop Ichthyol. 2013; 11(1):153-62.

Sanches EA, Marcos RM, Okawara RY, Caneppele D, Bombardelli RA, Romagosa E. Sperm motility parameters for Steindachneridion parahybae based on open-source software. J Appl Ichthyol. 2013; 29(5):1114-22.

Sanches EA, Okawara RY, Caneppele D, Neumann G, Bombardelli RA, Romagosa E. Storage of Steindachneridion parahybae oocytes at different temperatures. Anim Reprod Sci. 2014; 151(3):262-68

Sanches EA, Okawara RY, Caneppele D, Toledo CPR, Bombardelli RA, Romagosa E. Sperm characteristics of Steindachneridion parahybae (Steindachner, 1877) throughout $112 \mathrm{~h}$ of storage at four temperatures. J Appl Ichthyol. 2015; 31(S1):79-88.

Sargent JR, McEvoy L, Estevez A, Bell G, Bell M, Henderson J, Tocher D. Lipid nutrition of marine fish during early development: current status and future directions. Aquaculture. 1999; 179(1):217-29.

Sargent JR. Origins and functions of egg lipids: nutritional implications. In: Bromage NR, Roberts RJ, editors. Broodstock management and egg and larval quality. Oxford: Blackwell Sciences Ltd; 1995. p.353-372.
Sayer MDJ, Gibson RN, Atkinson RJB. Growth, diet and condition of goldsinny on the west coast of Scotland. J Fish Biol. 1995; 46(2):317-40.

Schreck CB, Contreras-Sanchez W, Fitzpatrick MS. Effects of stress on fish reproduction, gamete quality, and progeny. Aquaculture. 2001; 197(1):3-24.

Sheridan MA. Regulation of lipid metabolism in poikilothermic vertebrates. Comp Biochem Physiol B.1994; 107 (4):495-508.

Soengas JL, Sanmartín B, Barciela P, Aldegunde M, Rozas G. Changes in carbohydrate metabolism in domesticated rainbow trout (Oncorhynchus mykiss) related to spermatogenesis. Comp Biochem Physiol B. 1993; 105 (3/4):665-71.

Tocher DR. Metabolism and functions of lipids and fatty acids in teleost fish. Rev Fish Sci. 2003; 11(2):107-84.

Tyler CR, Sumpter JP. Oocyte growth and development in teleosts. Rev Fish Biol Fish. 1996; 6(3):287-318.

Vazzoler AEAM. Biologia e reprodução de peixes teleósteos: teoria e prática. Maringá: Eduem; 1996.

Vazzoler AEAM. Manual de métodos para estudos biológicos de populações de peixes - reprodução e crescimento. Brasília: CNPq; 1981.

Vieira VARO, Correia TG, Moreira RG. Effects of aluminum on the energetic substrates in neotropical freshwater Astyanax bimaculatus (Teleostei: Characidae) females. Comp Biochem Phys C. 2013; 157 (1):1-8.

Yaron Z, Sivan B. Reproduction. In: Evans DH, Claiborne JB, editors. The physiology of fishes, 3rd ed. New York: Taylor and Francis Group; 2006. p.344-372. 